\title{
Agurumyela's art of connection: Christopher Azaare's project of curating Gurensi history and culture
}

\author{
Anatoli Ignatov
}

On the morning of 14 December, Christopher Azaare and I hopped onto his sputtering old blue Honda motorcycle to make our way back to his Museum of Gurensi History in Gowrie. We had just completed an extended interview with the chief and elders of Zoko Kodorogo, a small village in the Upper East Region of Ghana. We wound our way on the narrow dusty pathway amidst the rocky outcrops and baobab trees that dotted this scenic part of the Sudanese savannah. En route, Azaare decided to add one more 'quick' stop to our itinerary and turned right at the next junction. We were now heading for the compound of the tindaana (earth custodian) of the neighbouring community, Zoko Kadare.

We parked the moto off the main road under the shade of a big tree. We took our shoes off, observing the ancestral taboo not to approach the tindaana's compound wearing footwear, and followed a narrow path to the earthen compound. After announcing our unexpected visit and a customary exchange of greetings, we were seated by an old man under a big baobab tree. An old woman walked out of the compound and offered us a calabash of water while we waited for the tindaana and his elders to gather. Such visits were part and parcel of Azaare's research repertoire. They have given credence to Azaare's local nickname of Agurumyela, a Gurene word meaning 'a person who digs into people's past'. Over the past forty years, these trips have allowed him to spin a vast web of connections between foreign researchers like me, Ghanaian public officials and academics, and traditional leaders and elders, who have all turned to him as an important source of local intellectual knowledge.

We were soon joined by the tindaana, his father, his brother and several elders. Commonly a descendant of the pioneer settlers, the tindaana is a traditional leader who acts as a trustee of community lands and a spiritual intermediary between the land spirits and the living. The institution of tindaanaship has recently risen in prominence with the intensification of land litigation and conflicts and land administration reforms in Ghana. To our surprise, the Kadare tindaana was a very young man who was attending the local senior high school (shown in the cover image of Azaare's Tindaanaship and Tindaanas in Traditional Gurensi (Frafra) Communities). He was selected by a soothsayer and was enskinned at the age of two or three years. The tindaana's father was assisting him with the

\footnotetext{
Anatoli Ignatov is an Associate Professor of Sustainable Development at Appalachian State University. He is currently completing a monograph titled Decolonizing Environmentalism: alternative ecologies of land in two traditions, which puts into dialogue Euro-American and African political thought. It explores land as a web of relations with various political struggles, agencies, cosmological claims, rituals and performances of sacrifice, speech and collective identities. His work has appeared in Political Theory, GeoHumanities and Theory and Event as well as in edited volumes. Email: anatoli@appstate.edu
} 
performance of sacrifices and teaching him about the complexities of tindaanaship. School, we were told, did not interfere with his spiritual duties.

We began the conversation by explaining our research 'mission', which was focused on documenting the hitherto unrecorded genealogy of Kadare tindaanaship and on the tindaana's and elders' views of the land, the ancestors and the institution's changing role in land management vis-à-vis chieftaincy. Azaare dived in with a question about how the name Kadare came about. The tindaana's father responded, narrating the origin story of the ancestors' migration from Sirigu in Kasena-Nankana. When his forefathers arrived at the village's present location, they realized that 'this place was nicer than the original site' and named it 'Kadare' (from Ti bo Kala yianne in Nankan or 'here is better than where they have migrated from'). Azaare followed up on the story with a question about the name of the first ancestor. A short conversation among the elders revealed that the first ancestors were three brothers - Amuna, Asabila and Ayangale - who settled at Akalisa and cleared the area, which at the time was 'very bushy'. During the discussion, Azaare took written notes of all the ancestors' and clan names in his notebook and kept probing deeper and deeper into next-of-kin family names, histories, cultural practices and genealogies.

'What was the order of succession of Kadare tindaama?' Azaare asked. ${ }^{1}$ The old men began recollecting: Tindaan-Kologo (the first tindaana from the Abagnabisi clan), Amiisa, Akecrarkologo, Awosesa, Atinga, Atooere, Akadana-Kologo, and Ake'cra-Kologo, the current tindaana. 'What are the different items of the tindaana's regalia?' Tankologo (sheep skin), wanne (calabash), lebere (triangle), black shirt, tails (of all sacrificed animals, including stray animals), kinkarega tied with man-puro (walking stick), tampoo (bag made of goat skin) and sua (knife). Azaare continued to ask clarifying questions about the list of regalia items, which drew loud laughter when everyone saw the confusion on my face. 'I am asking whether the tindaana must have a knife. They say this should be an essential tool,' explained Azaare and everyone laughed again.

We bought pito and kola for the group and then Azaare resumed his questions about Abagnabisi's totems: the monkey and the crocodile. 'The ancestor was a hunter. He got lost in the forest and it was the monkey that directed him,' explained one of the old men. 'What about the crocodile?' I inquired. 'When they die they turn into crocodiles,' answered the tindaana's father. The elders' subsequent recollection of tingana (earth god) names soon evolved into an animated conversation about the meaning of tina (earth) as a 'womb of the ancestors'. Azaare summarized the conversation for me: 'tina is like a womb. A woman has the womb and the tina gives birth. And if you die, it means that you are nourishing the earth. That's why the tima is the earth.' At the end of the discussion, the tindaana's brother took a sheet of paper and copied the list of tindaanas from Azaare's notes. We promised to provide the tindaana with a digital copy of the interview and to print out and bring back copies of the pictures that we took of the tindaana for Azaare's museum, which will include a room displaying the portraits of chiefs and tindaanas. We then said our goodbyes. On our way back to the moto, as the intense afternoon sun was beginning to set, Azaare in a typical fashion had come

\footnotetext{
${ }^{1}$ Tindaama is the plural of tindaana.

${ }^{2}$ Pito is a millet- or sorghum-based traditional alcoholic beverage in Ghana.
} 
up with yet another destination: 'We have time. Let's go to the house of Zoko Kadare Naba [chief's house].'

This was one of my early research trips with Chris Azaare, who has since become my intellectual and cultural mentor, friend and research collaborator. For the last eight years he has spent a great deal of time patiently engaging with me, sharing stories and introducing me to traditional leaders. He has been kindly answering my never-ending questions about the shifting meanings of vernacular concepts of land, property, personhood and authority, and how these changes have shaped the contemporary politics of land governance in the Upper East of Ghana. Azaare's understanding of Gurensi philosophy and history, traditional teachings and ethics, language and intellectual traditions is vast and complex. I have been impressed by the warm welcome that people give him and their readiness to leave whatever they are doing in order to sit down with us and answer his questions, showing how well-known, trusted and respected Azaare has become in these communities.

Azaare's research project is not merely about the precise recording of family names, history and relationships. It is also about building and maintaining long-term relationships and connections that his idiosyncratic research process both forges and nurtures. Some of these connections are temporal, linking past, present and future in non-linear ways and folding together the uneven chronologies of ancestral genealogies, succession lists and colonial archives with local seasonal calendars and market cycles. This is also a project of renaming and reclaiming the savannah landscape as a web of kinship relations between the living, the dead, animals and plants, using the indigenous Gurene names and terms. As diverse people converge around Azaare in search of knowledge, impromptu scholarly and community networks form and proliferate. I have recently been drawn into one such network that includes the vice president of the Ghana Association of Writers, an Italian PhD student, a Ghana Supreme Court justice, a Bolgatanga radio station owner, a prominent filmmaker in Accra, and two distinguished former Ghanaian government officials. Azaare connects us all as a mentor and we have joined efforts to assist him with the dissemination of his work. Because of this research, local people refer to Azaare as Agurumyela and my Ghanaian academic colleagues and I call him 'Professor' in recognition of his intellectual erudition.

Since 1976, Azaare has been archiving the histories and socio-cultural practices of the Gurensi and Boosi people of the Upper East Region of Ghana. Commonly described by anthropologists as 'stateless' societies of the northern Ghanaian savannah, the Gurensi and the Boosi have long been conceived as marginal to narratives of decolonization and social change within Ghana. In the words of colonial ethnographer Rattray (1932), these 'tribes' demarcated the 'Ashanti hinterland'; their intellectual traditions have received little research attention in comparison with the Mamprusi, Mossi and Dagomba zones of state building that surround them. ${ }^{3}$ Azaare has compiled genealogical maps of whole villages and clans in

\footnotetext{
${ }^{3}$ The majority of Gurensi and Boosi people live within and around Bolgatanga and Bongo traditional areas. Azaare's work shows an awareness that local settlement, clan and ethnic names are contingent and contested. The term 'Gurensi' is a controversial identification as some of the
} 
the Bolgatanga and Bongo traditional areas and has written over twenty multivolume manuscripts on the indigenous institutions of chieftaincy and tindaanaship, missionary activities, and anti-colonial resistance. He has also assiduously collected proverbs, family names and histories, information on indigenous tree species, taboos, totems and customs, and has incorporated them into various projects and frames of his own design. Today, chiefs, tindaanas and local residents are frequent callers or visitors to his compound in the hope of consulting his records when they face a difficult case of dispute resolution or a gap in their knowledge of settlement histories. Azaare is also in the process of turning his house in Gowrie into a museum of Gurensi history and culture, which can be viewed in the video tour of Azaare's museum as part of the supplementary materials published with this article. ${ }^{4}$ The museum is a meandering maze of dark rooms under construction, featuring painted walls, clay pots, cement sculptures of people and animals and cultural artefacts, as well as Azaare's library, a study, and a miniature earthen compound that he has constructed to honour traditional housebuilding practices. The supplementary materials also include a biographical narrative that offers further details about the range and diversity of Azaare's interests and occupations and the profusion of his outputs.

In the pages that follow, I share my reflections on Azaare as a platform for rethinking the meanings of 'African local intellectual'. First, I explore what motivates Azaare - a self-taught researcher outside the academic mainstream - to dedicate himself to a lifelong intellectual and cultural project of his own making to reclaim history and storying authority from Western academics. I focus in particular on the museum space that Azaare is building in Gowrie. That space is critical to an analysis of his project because it renders concrete his role as a curator of Gurensi orature in the present day. Azaare's task of restoring Gurensi and Boosi cultural history is not a matter of retrieving a standing reserve of information. Rather, it is a project of locating and arranging oral histories, rituals, proverbs, names and art objects in new ways. ${ }^{5}$ Azaare's approach blends creative

Gurensi's neighbours use it in a derogatory sense. In English-speaking conversations, and in conversations with Ghanaians unfamiliar with the Upper East, one often hears 'Frafra', a colonial term derived from a local greeting, which lumps together the Gurensi and the Boosi alongside the Nabnam and the Tallensi (and their respective languages as 'Farafara'). Azaare belongs to a school of traditionalists who insist on the use of 'Gurensi'. In his view, the term should be best understood as a political choice to contest the colonial ethnicization of his people, even if this choice also runs the risk of consolidating an ethnic identity that he admits to be fluid, multiple and also partly defined by outsiders:

outsiders still regard them as a single ethnic community - Frafras - and their language as Farafara. Frafra is derived from a local greeting, which corresponds to the English phrase 'thank you' or 'the same to you' (or sometimes 'good morning'), and was corrupted by the colonial administration ... these days, to call any of these four ethnic groups within the BoNaBoTo Area 'Frafras' has no meaning and no one will respond to it ... They have resisted the use of the name Frafra and have wanted their original ethnic names - Gurensi, Nabnams, Boosi, and Talensi - substituted. (Azaare 2017: 135)

${ }^{4}$ The video can be viewed at $<$ https://doi.org/10.1017/S000197202000025X>.

${ }^{5}$ C Curating an African anticolonial archive ... is not a matter of retrieving from some pre-existing, already collected body of work, but rather the project of locating (and dislocating) texts, ideas, structures, music, images, and the like, and arranging them together in new ways' (Kamola and 
curation and archiving in ways that unsettle conventional disciplinary notions of expertise and knowledge.

Second, I discuss Azaare's genealogical method. I focus on his book Tindaanaship and Tindaanas in Traditional Gurensi (Frafra) Communities, which offers substantive contributions to Ghanaian historiography and law and to the fields of African studies and indigenous research methodologies. It furnishes a rich empirical account of the institution of tindaanas (earth priests), its origins, clan relationships and indigenous Gurene categorizations of land relations and uses, all of which are still poorly researched and little understood within Ghana. The manuscript also offers exhaustive lists of tindaanas' names, earth shrines, taboos, totems and rites; it documents procedures for nomination and selection of tindaanas that exceed the empirical and ethnographic detail and richness of available accounts. ${ }^{6}$ The sample text from the book included in this issue of Africa is merely an illustration of the full-length book, which is available to explore as part of the supplementary materials, along with associated texts such as Azaare's biographical narrative, fieldnotes and videos of his museum.

I have deliberately sought not to academicize Azaare's work. By this I mean that I have avoided the standard academic treatment of presenting Azaare's work and then problematizing its assumptions, its author and its social context. ${ }^{7}$ Instead, I invite readers to carve out a space to hear Azaare's work as it speaks for itself and to appreciate the importance of his own insights into how intellectual knowledge works. Refusing a narrowly conceived role of a 'native informant' or 'traditional oracle', Azaare shows us instead that he is a complicated thinker and extremely dedicated community intellectual, working within many traditions, with many penetrating insights but many blind spots as well. He is an autodidact who blends repertoires and methods in unsettling hybrids and shows extraordinary devotion to pursuing historical inquiries without institutional training, support or rewards. In the biographical narrative, I describe how Azaare's project has been shaped by his self-education and record of volunteering as a teacher at Gowrie Senior High and other local schools from 1967 to 2006, without ever being formally employed by any of these schools; by the mix of his training in meteorology at Legon and his custodianship of the earth gods, through which he acquired knowledge of traditional weather forecasting; by his field trips to the National Archives in Accra and to local village compounds; and by his periodic engagements with teachers, missionaries, development planners and Ghanaian and foreign academics. The scope of his intellectual project, which

\footnotetext{
el-Malik 2017: 6). I am indebted to Shiera Malik and Jacqueline Ignatova for drawing my attention to Azaare's role as a curator of history.

${ }^{6}$ For example, see Allman and Parker (2005), Cardinall (1920), Eyre-Smith (1933), Fortes (1945; 1949), Fortes and Evans-Pritchard (1940), Lund (2008), Pogucki (1955) and Rattray (1932). See also National Archives of Ghana (NAG), ADM 56/1/91 Laws and customs, Northern Territories, 1908; NAG ADM 56/1/113 Land tenure, Northern Province, 1911-1928; NAG ADM 56/1/375 Land tenure, 1924-1931.

${ }^{7}$ Here, I am not saying that an understanding of Azaare's context is not needed. Knowledge of Azaare's social and historical context is required to illuminate his intellectual project in the same way in which the contexts of thinkers such as Kant or Fanon are necessary to fully understand their philosophies. The idea is not to provincialize or minimize the significance of such strands of intellectual production but to enrich them and elucidate them further.
} 
integrates his museum, sculptures, archival research, fieldwork, teaching and community outreach, cannot be truly appreciated simply in terms of the value of his accumulated knowledge and contributions to mainstream Ghanaian scholarship. First and foremost, Azaare is a public intellectual who also writes and creates profusely, half internal and half external to the cultural worlds and histories that he is documenting. ${ }^{8}$

\section{'Your work will make the white man also fear us': reclaiming and decolonizing Gurensi history ${ }^{9}$}

Chris Azaare often speaks about his motivation to embark on this wide-ranging, long-term process of collecting information and data:

It's quoted in part of my book: in one of the books of Bible or Joel, the Lord said that 'I will restore to you what the locust hath eaten' - that is, most of our cultural practices are getting lost so my aim is to restore the cultural traditions of my people. That was one of my aims: to restore them and make sure that those who come later, the next generation, will come to read about our culture and gods from the beginning. ${ }^{10}$

For Azaare, research is not a neutral or distant academic exercise. It is a highstakes commitment to intervene in conditions of enduring colonial inequalities in order to reclaim authorship of one's own culture as its active archiver and creator. In the preface to his manuscript on tindaanaship, he notes that 'both Western and missionary education has taught us a great deal about who they are, where they came from and why they are here. Our situation is quite disheartened because we cannot tell who we are, what we are, where we came from.' Although his manuscripts are written for multiple audiences - international, academic and vernacular - his primary audience remains the Gurensi and Boosi people themselves. His books are intended to be 'teaching histories' that equip the next generations with an official account of their collective story (see Smith 2012: 145). They seek to decolonize minds by challenging the youth to reflect on why they are 'unable to trace their origins, migrations and let alone their family genealogies' but can give 'perfect answers' on 'foreign history' questions about Jesus, Rome and Asante. Azaare's project insists that Amuna's migration story and Abagnabisi's relationship with the monkey must also be acknowledged as being worthy of history.

Azaare sees this task of 'restoring' Gurensi culture as a single unified project comprising manifold study areas, rather than separate research projects:

Culture is diverse and there is so much, starting from childbirth, marriage, adulthood and so forth ... it also includes their language, their economic activities, so all these are within the context of Gurensi culture. I do it as a whole. When I used to go around, I used to have

\footnotetext{
${ }^{8}$ Here, I am grateful to Karin Barber for her illuminating insights into Azaare's role as a community intellectual.

${ }^{9}$ See the preface of Azaare's Tindaanaship and Tindaanas in Traditional Gurensi (Frafra) Communities.

${ }^{10}$ Discussion with Chris Azaare and Helen Azupogo, Gowrie, 27 July 2018.
} 
a broad questionnaire for the language side, why they give names, the proverbs. For the answers I didn't have a tape recorder. If I miss, I may not be able to go back ... I then settle down and put them into books as you see them. ${ }^{11}$

Childbirth was Azaare's first major study area. At first he wanted to find out from his mother, who was a traditional birth attendant, why he was given the names Azaare and Anabila. He learned more about how she did her work and subsequently extended his inquiries to document marriage practices, funeral rites, the ancestors and earth gods, completing a holistic study of the Gurensi lifecycle in all of its integrated cultural, political, economic, spiritual and social dimensions. Today, Chris is content with the scope and breadth of his long-term research: 'I tackled every aspect of my culture ... I am satisfied. Not a single area has been left. ${ }^{12}$

As with other efforts to rescue dying African traditions by writing them down, ${ }^{13}$ Azaare's process of documenting resonates in some ways with colonial and anthropological constructions of African customs as a holistic, monolithic and ethnically bounded body of knowledge that can be stored and passed on to succeeding generations. His aspiration to document culture 'as a whole' without leaving out a 'single area' sometimes leads him to generate normative summaries and generalized formulations of his field research. Such summaries dominate the earlier chapters of the manuscript on tindaanaship. In contrast, the later genealogical chapters provide rich accounts of adaptations of tradition and migration and settlement histories, according to competing schools of elders who reveal custom as fluid, contested and negotiable. These accounts highlight variability and diversity within and across Gurensi communities and trouble colonial preoccupations with origin and geography as the dominant lens through which to understand 'native' cultures. In the next section, I suggest that this syncretism of Azaare's decolonial project may be brought out by enlisting the concepts of curation, orature and endogenous knowledge, rather than unadulterated oppositions between foreign and indigenous knowledge.

\section{Curating the past beyond the academy}

The project of restoring a dynamic tradition that is constantly changing, Azaare explained to me once, means that the process of collection, preservation and

\footnotetext{
${ }^{11}$ Ibid.

${ }^{12}$ Ibid.

${ }^{13}$ Azaare's project to decolonize knowledge can be situated within a well-established tradition of African intellectuals and autodidacts, such as the writings of Yoruba chief Isaac Babalola Akinyele (1959) on the history of Ibadan, Akiga Sai (2015) on the history of Tiv, and S. W. D. K. Gandah (Gandah and Lentz 2012) on the history of his father, who was an influential Dagara chief in north-western Ghana. Whereas Azaare is not familiar with these thinkers and does not know any similar local intellectuals in north-eastern Ghana, in past conversations he has noted the work of Victor Aboya, a friend of his grandfather and principal informant of colonial anthropologist R. S. Rattray. Aboya's writings on Nankani culture were incorporated in Rattray's The Tribes of the Ashanti Hinterland (1932: 130-228). In addition to Aboya, Azaare has also drawn parallels between his own documentation project and the projects of Ghanaian academics such as A. A. Iliasu (n.d.) and Yakubu Saaka (1978) on Mamprugu history and politics, Albert Awedoba (2000) on Kasena culture, and Kropp Dakubu (1995) on northern Ghanaian languages.
} 
documentation is also a process of artistic and creative invention. More than a chronicler of culture and history, Azaare is a curator of Gurensi and Boosi orature. He collects Gurene pots and cultural objects for the museum but also carves beautiful cement sculptures. He elicits oral traditions and stories by sitting down with traditional knowledge-holders such as the Kadare tindaana's family and elders but he has also devoted years of research at the Accra archives verifying dates, events and stories. For Azaare, the practice of research cannot be separated from a corollary artistic practice of according a physical and material aspect to abstract categories of culture:

I bring all those things in my museum just to show to the youth that that's how the culture existed. These are the physical things you can see. That's why I made them. Modelling is an aspect of trying to create. Maybe, if it is not the exact thing ... creating what some of the items look like ... Like the tindaana, we have the skins and other things. If you say 'Our ancestors used to wear skins' and you do not show the fellow what a skin is, it will be useless. So I wanted to bring both - creating the physical aspect of the culture and the academic aspect. ${ }^{14}$

The integrative nature of Azaare's work elides the boundaries between preservation and creation, art and science, and the written, the oral and the expression of art objects. Unlike the focus of much Western art and humanities on soleauthored projects, Azaare's project is also a manifestation of the collective creativity that defines the orature of a people that precedes him. At once a public intellectual, researcher, sculptor and storyteller, Azaare blends art forms and genres of history to curate culture in ways that remain loyal to the spontaneity and lived dynamism of vernacular lives.

Ugandan linguist Pio Zirimu coined the term 'orature' to counter the tendency to treat the oral traditions of African thought as an inferior stage in a linear evolution towards modern literature and writing. Zirimu defined orature as 'the use of utterance as an aesthetic means of expression' characterized by the fusion of all art forms (quoted in Ngũgĩ wa Thiong'o 1998: 111). 'The key in all these elements of orature,' Ngũgĩ wa Thiong'o observes, 'is their interpenetration. Central to them, is performance' (2012: 80-1). Orature also gives expression to the 'language of nature' by proliferating stories of the various connections and interdependencies between humans and nature, be it the tingana in Kadare in which the ancestors find new abodes among the living or people's relationships of kinship with the monkey and crocodile (ibid.: 15).

Azaare's curation of orature exposes the way in which the process of knowledge production by African local intellectuals is creative, relational and embodied. Teaching histories are not only written down in Azaare's manuscripts but also inscribed into the traditional earthen compounds, sacrifices to the earth gods, war dances, tindaama regalia, names, songs, proverbs, Sirigu pots and cement sculptures through which he guides us. Each tour of the museum that I have been given - whether joining local residents, traditional leaders or international visitors - transforms it into a stage where Gurensi orature is performed. The tour requires each visitor to crawl through narrow earthen entrances, climb up

\footnotetext{
${ }^{14}$ Discussion with Chris Azaare and Helen Azupogo, Gowrie, 27 July 2018.
} 
steep stairs and walk on a zinc roof in order to retrace the steps of the archer positioning to defend the compound from slave raiders or to descend into a narrow corridor to observe women's preparation of the evening meal. The museum becomes a space where researcher and researched, curator and audience actively interact and share knowledge with one another.

This performative register of Azaare's work accentuates knowledge generation not only as an interactive and creative embodied practice but also as an endogenous process of recentring African intellectual production. The term 'endogenous', for Hountondji, 'evokes the origin of the kind of knowledge in question by identifying it as an internal product drawn from a given cultural background, as opposed to another category of knowledge which would be imported from elsewhere' (Hountondji 1997: 17). Such knowledge is dynamic, rather than static, as it is characterized by a 'never-ending movement of interiorisation and appropriation of values derived from elsewhere' (ibid.: 18). It is defined by Azaare's own mastery over cultural borrowings, such as his use of British colonial archives or biblical quotations in support of elders' oral testimonies, and his choice of cement as a 'traditional' art medium.

\section{Family trees as methodology}

In Azaare's view, his most notable innovation is the meticulous and painstaking process of tracing and crafting family trees and genealogies:

I have created the family genealogies which have not been captured by most researchers. That is the only way you can trace to find out relationships. I have to create this to let the family or the clan know that they are one family or one clan. So I departed from the other side of taking history without letting them know their relationship ... That was the creativity I decided to include for easier understanding. ${ }^{15}$

Over the past forty years his genealogies have come to encompass nearly every community within the Bolgatanga and Bongo traditional areas. The genealogies have allowed him to document and make visible neglected or previously unmapped histories of migration and settlement and relationships between families, clans and villages. They have also enabled him to locate dates of pioneer settlers' arrival and ascertain whether family members are qualified to become chiefs or tindaanas within that family. Drawing on Azaare's avid interest in biology and maths, which I discuss in his biography online, these histories and relationships have been represented by the use of genealogical charts and family trees. The tree model, in his view, expresses best an anatomical correspondence between the growth of village sections and clans and the lifecycles of biological organisms. ${ }^{16}$

This process of creating family trees in order 'to let the family or the clan know that they are one family or one clan' can be understood as an art of connection that positions families in Bolgatanga and Bongo in kinship relationships with

\footnotetext{
${ }^{15}$ Ibid.

${ }^{16}$ Personal communication with Azaare, September 2019.
} 
neighbouring people and communities. Connecting here also involves linking people to their ancestral lands, and to animals and plants via collective identifications with totems and taboos. ${ }^{17} \mathrm{It}$ is a creative process of drawing and remaking the links between collective identities, belonging and place. Azaare's project of connecting is recognized in Bolgatanga and in 2017 he was invited to host a history show on Tanga FM, a local Gurene radio station. During its year on air, Azaare's show has made many local residents realize that they are literally related to one another, minimizing tensions in certain families and communities.

Azaare is aware that his genealogical method distinguishes his research from the work of other scholars of northern Ghana. He notes that most researchers do not 'want to go deep into history' - and, even if they do, they lack the situated, local knowledge to pursue such inquiry:

If you are a foreigner you would not go deep into their family matters. But since I am born and bred here, when you are hiding facts I, by all means, will know! So that's the difference. A researcher will go there and they will say, 'No, we don't give names because it is a taboo.' Even some of the chiefs and the tindaanas will not give you their actual names ... Let alone to go in to find out their family names, dead ones. Because when I used to carry out this thing I'll ask the old men and they will say, 'Oh, this man is dead, what do I want his name for?' [laughs] ... You, the foreigner or the researcher will not like to go into detail about the names of dead people. ${ }^{18}$

Azaare knows that the elders' reference to taboo in their refusal to share the names of dead relatives is a way of protecting sensitive information by citing a commonly held belief, rather than an actually existing ancestral prescription. As someone 'born and bred' in the traditional area, he can tell belief from taboo and has devised a culturally appropriate strategy for eliciting such information, and thereby uncover 'deeper' layers of family histories.

The manuscript Tindaanaship and Tindaanas in Traditional Gurensi (Frafra) Communities illustrates the originality of Azaare's genealogical method. Whereas chiefs occupy the customary office in most of Ghana, in the Upper East region customary offices are split between tindaanas, chiefs and clan/ family heads. Every community near Bolgatanga and Bongo has a tindaana: the title of the office is derived from tima (i.e. the term for 'land' in Gurene, which includes both the territory of a community and the community itself) and daana (which means 'owner of' or 'trustee'). Tina daana thus designates the trusteeship responsible for the spiritual oversight of community land. The tindaana performs sacrifices to the land spirits on behalf of the whole community

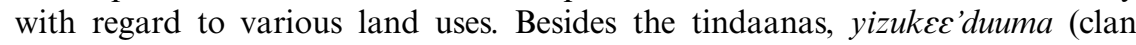
heads) oversee clan lands. Naduma (chiefs) usually belong to landowning clans and families and can own land by virtue of their membership in the clan/family. In Gurene, a common statement by elders that Azaare cites in the book differentiates between the office of the tindaana and naba (singular of naduma): Naba sus la a neriba, tindaana sus la a tina (i.e. 'the chief is for the people, the tindaana is for

\footnotetext{
${ }^{17}$ Azaare's genealogical method can be situated within Linda Smith's discussion of connecting and creating as two decolonizing projects that are currently being pursued by indigenous communities (2012: 149-50).

${ }^{18}$ Discussion with Chris Azaare and Helen Azupogo, Gowrie, 27 July 2018.
} 
the land'). Transactions in land had rarely been the business of chiefs until the colonial period, when, by appointing and in many places 'inventing' chiefs, the colonial administration delegated land control to them, which they retained after independence (see, for example, Lund 2008; Rattray 1932). But, in practice, land administration by tindaanas and clan elders continued, remaining invisible to the law until 1979 when the constitution divested the state of its trusteeship over most lands in the Northern and Upper regions and the need to clarify the question of to whom these lands were to be given became critical (Lund 2008: 19). This development produced new conditions for the reinterpretation of customary tenure arrangements, intensifying struggles over ownership among tindaanas, chiefs and family heads. The recent revival of tindaanas and the formation of the Upper East Regional Tindaama Council to contest the privileged role of chiefs as grantors of land for development purposes have further complicated these struggles.

Thus, the publication of Azaare's manuscript in Africa is very timely. Apart from the early writings of Rattray (1932), Cardinall (1920), Fortes (1945; 1949) and Fortes and Evans-Pritchard (1940), the tindaanaship has been less studied than the chieftaincy. Notable exceptions include works by Allman and Parker (2005), Lentz (2013), Lund (2008), Tonah (2008), Kasanga and Kotey (2001), MacGaffey (2013) and Yaro (2012). While these works have cast light on the changing role of the tindaana as land custodian or religious leader under historical pressures of invention and commoditization of custom, Azaare's book probes into 'deeper' layers of history that are not easily available to these authors, such as the hitherto unrecorded and little known genealogies of tindaama clans in Bongo and Bolgatanga.

The book also contributes to the study of Ghana's customary land law, which has been largely constructed and shaped by a series of judicial pronouncements, case law and authoritative works of jurists such as S. K. B. Asante (1975), Ollennu (1962), Bentsi-Enchill (1964) and Woodman (1996), which have focused exclusively on the south of Ghana. Azaare's chapters on Gurensi divisions and categories of land and traditional title to ownership bring the north of Ghana into the orbit of such legal scholarship. In particular, Chapters 4 and 5 enrich and complicate legal research on the customary hierarchy of land interests in Ghana. ${ }^{19}$ Most of the latter relies on imported judicial norms and categories such as 'allodial' title and 'usufruct' to make legible to Ghana's system of legal pluralism land relations such as the Gurene samanc. ${ }^{20}$ In contrast, Azaare prompts the reader to understand such relations on their own terms, in accordance with the local contexts and idioms in which they are negotiated, rather than through the language of customary law that Ghana has inherited from British colonialism.

Furthermore, Azaare's genealogical method, which allows him to trace migration and settlement histories of founding ancestors, challenges the conventional view of tindaanas as descendants of pioneer settlers that is widely adopted by both scholars and locals. His research shows that tindaamabisi (earth priests'

\footnotetext{
${ }^{19}$ For a comprehensive study of Gurensi customary land law, see Volume III of the ACLP Project's report on customary law on land and family in Ghana (ACLP 2011).

${ }^{20}$ Samane refers to a farm or field for cultivation or residential land (see Chapter 4 of Azaare's book).
} 
clans) are often related to but different from timabisi (pioneer, first settlers' clans), an identity that is commonly presumed or taken for granted:

When researchers come, they will say, 'The original man who settled there is the land owner.' It is through the family trees that one will be able to know that it is a sister's son or people [who] occupied the area or maybe it is a gift to the fellow. Most of the researchers have not gone to make that distinction ... these different categories have not been identified. And they didn't expand it, like I said. A community was given one name - that is tima - and researchers only know that tima is one and they say that the tindaana is in charge of the tima. But the tindaana is only responsible for the soil and then the community is headed by the chief ... the chief walks on shoes, the tindaana does not walk on [shoes] because he is directly connected to the soil. That's why he walks barefoot ... the tingane is like a skin. When you tread on it, you can puncture it. That's another difference. Most researchers still are bent on that the landowners are the original settlers. ${ }^{21}$

Here, Azaare seeks to reclaim history and curating authority from academics. According to Azaare's genealogies, Gurensi tindaanaship often originated from indigenous land- and power-sharing arrangements, for example between mothers' brothers and sisters' sons, rather than first settlement or occupation. In Chapter 2, he identifies four categories of mode of acquisition of tindaanaship: by first occupation, conquest, gift, and sister's son type. In many parts of the Bongo and Bolgatanga areas, the family trees reveal that it is the sister's son tindaanaship that dominates. The original settlers (tiqabisi) delegated jurisdiction over land and the earth gods to their sister's son or daughter's sons (yiwiiakoma or ta 'apa-koma), even though the latter were not entitled to the tindaanaship. In many cases, women fled their husbands' homes following unwelcome or unhappy marriages, hunger or accusations of witchcraft to live with their brothers. The children of these sisters of first-comers, who were marginalized and landless in society, were given jurisdiction over a portion of the community land and the earth gods, making them responsible for allocating lands to strangers and for sacrificial rites pertaining to the village as a whole. The sister's sons were often required to receive items such as millet flour and animals and pour libations to the gods.

In Azaare's view, the sister's son tindaanaship is an indigenous social and moral arrangement that ensures that the marginalized and hungry within tindaanas' families and clans are given access to land and food. This type of tindaanaship has emerged as a power-sharing aspect of Gurensi moral economy that seeks to advance food security, generosity and equity, an aspect that has not been documented before in the Gurensi and Boosi areas. The sister's son tindaanaship has also functioned as a traditional conflict resolution institution. As custodians of the land, tindaanas already have a spiritual mandate to prevent violence and warfare and to propitiate the earth when blood is spilled. The sister's son, in addition, is strategically positioned vis-à-vis his mother's clan to mediate in family conflicts. ${ }^{22}$ Unlike his brothers, Azaare explains, he is regarded as someone impartial who can be trusted with the custody of earth gods without fear of manipulating them in the service of any one faction of the family or clan.

\footnotetext{
${ }^{21}$ Discussion with Chris Azaare and Helen Azupogo, Gowrie, 27 July 2018.

${ }^{22}$ This peace function of a sister's sons is discussed in Awedoba et al. (2011: 254).
} 
On the one hand, without Azaare's family trees, institutions such as the sister's son tindaanaship would remain largely invisible to researchers, court justices and officials at Ghana's Land Commission. The publication of Azaare's book might contribute to the reduction of land conflicts and disputes as the histories and relationships between first-comer and landowning families and clans in the Upper East Region are clarified and made public for the first time. Azaare's original research on tindaanaship also provides a rare glimpse into 'deeper' and socially hidden registers of Gurensi moral economy and history, which include neglected indigenous democratizing principles of collectivity and power sharing.

On the other hand, Gurensi and Boosi oral registries of ancestral settlement, migration and institutional transformation reflect intellectual traditions of intergenerational thought that cannot be easily translated into the lexicons of academic historiography and legal pluralism. By imposing a specific knowledge order on the blend of oral and archival material that he curates, is Azaare granting these traditions due recognition as dynamic and fluid sources of indigenous law, identity and political legitimacy? Is it possible that Azaare's process of rendering these relationships systematic through family trees and succession lists might also be inadvertently evacuating some of the lived experiences of negotiability and contestation that they embody? Like the royal genealogies of neighbouring Mamprusi, Azaare's project aims to provide extra depth and visibility to hitherto overlooked Gurensi histories, categories and forms of leadership. Yet his chosen methodology for decolonizing history and for confronting the unequal resources, access and ownership of knowledge production about the Upper East of Ghana might also appear to be depoliticized. Azaare's 'deep histories' often include normative descriptions of Gurensi society that tend to treat genealogical kinship as an ancestral regulatory system without much room for political agency, flexibility or negotiation.

Intellectual thinkers such as Foucault (1972), Derrida (1996), Spivak (1999) and Trouillot (1995) have expanded our understanding of the notion of 'archive' as a heterogeneous assemblage of thought and practice that entwines a plurality of texts, authors and statements, hegemonic and counter-hegemonic systems of knowledge production and categorizing, and rules that govern what can be said, what is remembered, and what is overlooked and silenced. ${ }^{23}$ Azaare's project, which contests the dominant role of Western scholars to write the histories of his people's cultural struggles, and advances instead a single authoritative account of his own making, is also embedded in uneven relationships of power. The genealogical maps and lists that make it possible to give voice to the indigenous Gurensi discourses that Azaare seeks to 'restore' might continue to silence the historical agency of vulnerable groups such as women, children and migrants to insert themselves in contemporary narratives of landownership and social change in northern Ghana. Can Azaare's practice of reclaiming history, based on a research design that privileges stories of first ancestors, also be understood

\footnotetext{
${ }^{23}$ See also Branwen Gruffydd Jones on the contested politics of intellectual knowledge production in the African anti-colonial archive: 'How can we access and engage with the anticolonial archive, from our own time, in a manner which avoids unwittingly ... reproducing the underlying rules of discursive and disciplinary formations which constitute the dominant archive against which these struggles were waged?' (2017: 71).
} 
as a re-performance of patriarchal authority that obscures alternative accounts of establishing claims to land? Whereas Azaare's book might offer valuable resources for addressing land conflicts that arise from power struggles among chiefs, tindaanas and landowning families, it may be less effective in clarifying the status of conflicts that manifest the limits and gender biases of customary systems of land tenure and inheritance.

Inescapably, a careful exploration of Azaare's enterprise in its totality would highlight both its limitations and blind spots and its originality and achievements. The latter showcase the lifelong dedication of an African local intellectual to curate knowledge, moving outside the academic mainstream towards contemporary aims such as building relationships among marginalized Ghanaian communities. The manuscript on tindaanaship should be read as an act of curation that summons a particular kind of relationship between author, text and audience, and not merely an encyclopaedic assemblage of customs and succession lists that has been retrieved for an anonymous readership with little room for interpretation. I encourage the readers of Africa to approach the manuscript on its own terms, as part of Azaare's hybrid intellectual project, rather than on the terms of academic historiography. Blending the boundaries between oral and written culture, his syncretic method of knowledge production generates exhaustive written documentation that continuously furnishes him with resources for partial oral exegesis. Azaare anticipates that his readership will consist of Gurensi and Boosi community members, lawyers, public officials and academics who would first turn to the book as a resource for specific inquiries and then hopefully would continue to read. When Azaare addresses such audiences on the radio or at his museum, or when chiefs, tindaanas and local residents visit his house for information, he seldom reads from notes and manuscripts or provides written documents. He speaks from memory and reactivates local histories by oralizing his fieldwork notes in ways that weave connections among all readers and visitors who respect the quality of his exposition. Agurumyela's art of connection empowers local communities to reclaim authorship of their own history and culture, but on its own syncretic and differentiated terms. With each moto trip, museum tour or clarification of a history that local people are confused by, I have come to appreciate Azaare's deep commitment to the responsible relationality of Gurensi orature. The more people read his manuscripts or become immersed in the museum tour, the more they come to know and understand history from the point of view of a relative and co-participant in his story, rather than that of a detached reader and spectator. Without this orientation, for Azaare, the whole project of restoring history would be of limited value.

\section{Acknowledgements}

I am deeply grateful to Chris Azaare for his friendship and mentorship, and for his willingness to dedicate hours sharing his vast knowledge and experiences with me on the bench in front of his museum in Gowrie, over the phone, and during our collaborative research trips. I also wish to thank Abel Atimbire for his generous enthusiasm to take time off his taxi business in Bolgatanga in order to assist with the logistics of Azaare's documentation project. I am also indebted to Helen Azupogo for her assistance with the preparation of Azaare's full-length manuscript and biographical narrative, and to Domenico Cristofaro for his editorial work on Parts II and III of the manuscript. Warm thanks are 
also due to Fara Jim Awindor for his outstanding camerawork and permission to make available to the readers of Africa the video material from Azaare's museum. I am most grateful to Jacqueline Ignatova, Shiera Malik and Isaac Kamola, whose incisive feedback and ideas about Azaare's overlapping roles as an intellectual, museum curator, teacher and artist have enriched the earlier drafts of this article and the preparation of supplementary materials. As co-editors of Politics of African Anticolonial Archive, Shiera and Isaac also invited Azaare's chapter contribution, recognizing the value of his research and adding an important voice to the edited book from an African autodidact not formally trained within the academy. I also wish to thank Rebecca Witter, Aniseh Bro, Jessica Martell and the two anonymous Africa reviewers for their critical comments on the wider contextualization of Azaare's research that have allowed me to accentuate the innovative and hybrid nature of Azaare's intellectual project.

\section{Supplementary materials}

The following supplementary materials are available with the online version of this article at $<$ https://doi.org/10.1017/S000197202000025X>:

1. Christopher Azaare's full-length manuscript Tindaanaship and Tindaanas in Traditional Gurensi (Frafra) Communities.

2. A video tour of Azaare's museum in Gowrie (filmed by Fara Jim Awindor in July 2017).

3. A video interview with Azaare at his museum (filmed by Fara Jim Awindor in July 2018).

4. A biographical narrative of Azaare.

5. Scans of Azaare's fieldnotes and genealogical maps.

\section{References}

ACLP (2011) 'Report on the pilot phase of ascertainment and codification of customary law on land and family in Ghana. Volume III'. Accra: Project Secretariat of the ACLP, National House of Chiefs and Law Reform Commission.

Akiga Sai, B. (2015) The History of the Tiv. Translated by H. Bergsma, M. Akiga et al. London and Ibadan: International African Institute and Bookcraft.

Akinyele, I. B. (1959) Iwe Itan Ibadan ati die ninu awon ilu agbegbe re bi Iwo, Oshogbo, ati Ikirun, 3rd edition. Exeter: James Townsend.

Allman, J. and J. Parker (2005) Tongnaab: the history of a West African god. Bloomington IN: Indiana University Press.

Asante, S. K. B. (1975) Property Law and Social Goals in Ghana, 1844-1966. Accra: Ghana Universities Press.

Awedoba, A. (2000) An Introduction to Kasena Society and Culture through their Proverbs. Lanham MD: University Press of America.

Awedoba, A. K., E. Mahama, S. Kuuire and F. Longi (2011) An Ethnographic Study of Northern Ghanaian Conflicts: towards a sustainable peace. Accra: Sub-Saharan Publishers.

Azaare, C. (2017) 'Recollections of past events of British colonial rule in northern Ghana, 1900-1956' in S. S. el-Malik and I. Kamola (eds), Politics of African Anticolonial Archive. Lanham MD: Rowman and Littlefield. 
Bentsi-Enchill, K. (1964) Ghana Land Law: an exposition, analysis and critique. Lagos: African Universities Press.

Cardinall, A. W. (1920) The Natives of the Northern Territories of the Gold Coast: their customs, religion and folklore. London: Routledge.

Derrida, J. (1996) Archive Fever: a Freudian impression. Translated by E. Prenowitz. Chicago IL: University of Chicago Press.

Eyre-Smith, St. J. (1933) A Brief Review of the History and Social Organisation of the Peoples of the Northern Territories of the Gold Coast. Accra: Government Printer.

Fortes, M. (1945) The Dynamics of the Clanship among the Tallensi: being the first part of an analysis of the social structure of the Trans-Volta tribe. London: Oxford University Press for the International African Institute.

Fortes, M. (1949) The Web of Kinship among the Tallensi: the second part of an analysis of the social structure of a Trans-Volta tribe. London: Oxford University Press for the International African Institute.

Fortes, M. and E. E. Evans-Pritchard (eds) (1940) African Political Systems. London: Oxford University Press for the International African Institute.

Foucault, M. (1972) Archaeology of Knowledge. Translated by A. M. S. Smith. New York NY: Pantheon Books.

Gandah, S. W. D. K. and C. Lentz (2012) 'Gandah-Yir: the house of the brave. The biography of a northern Ghanaian Chief (ca. 1872-1950)', Africa 82 (3): 356-67.

Hountondji, P. J. (1997) 'Introduction: recentering Africa' in P. J. Hountondji (ed.), Endogenous Knowledge: research trails. Dakar: CODESRIA.

Iliasu, A. A. (n.d.) Mamprugu: the oral traditions of its peoples. Volume 1. Legon: Department of History, University of Ghana.

Jones, B. G. (2017) 'Comradeship, committed and conscious: the anticolonial archive speaks to our times' in S. S. el-Malik and I. Kamola (eds), Politics of African Anticolonial Archive. Lanham MD: Rowman and Littlefield.

Kamola, I. and S. S. el-Malik (2017) 'Introduction: politics of African anticolonial archive' in S. S. el-Malik and I. Kamola (eds), Politics of African Anticolonial Archive. Lanham MD: Rowman and Littlefield.

Kasanga, K. and N. A. Kotey (2001) Land Management in Ghana: building on tradition and modernity. London: International Institute for Environment and Development.

Kropp Dakubu, M. E. (1995) A Grammar of Gurune: trial edition. Legon: Language Centre, University of Ghana.

Lentz, C. (2013) Land, Mobility and Belonging in West Africa. Bloomington IN: Indiana University Press.

Lund, C. (2008) Local Politics and the Dynamics of Property in Africa. Cambridge: Cambridge University Press.

MacGaffey, W. (2013) Chiefs, Priests, and Praise-singers: history, politics, and land ownership in northern Ghana. Charlottesville VA: University of Virginia Press.

Ngũgĩ wa Thiong'o (1998) Penpoints, Gunpoints and Dreams: towards a critical theory of the arts and the state in Africa. Oxford: Oxford University Press.

Ngũgĩ wa Thiong'o (2012) Globalectics: theory and the politics of knowing. New York NY: Columbia University Press.

Ollennu, N. A. (1962) Principles of Customary Land Law in Ghana. London: Sweet and Maxwell. 
Pogucki, R. J. H. (1955) Gold Coast Tenure. Volume I: A survey of land tenure in customary law of the Protectorate of the Northern Territories. Accra: Lands Department.

Rattray, R. S. (1932) The Tribes of the Ashanti Hinterland. London: Oxford University Press.

Saaka, Y. (1978) Local Government and Political Change in Northern Ghana. Washington DC: University Press of America.

Smith, L. T. (2012) Decolonizing Methodologies: research and indigenous peoples, 2nd edition. London: Zed Books.

Spivak, G. C. (1999) A Critique of Postcolonial Reason: toward a history of the vanishing present. Cambridge MA: Harvard University Press.

Tonah, S. (2008) 'Chiefs, earth priests and the state: irrigation agriculture, competing institutions and the transformation of land tenure arrangements in northeastern Ghana' in J. Ubink and K. S. Amanor (eds), Contesting Land and Custom in Ghana: state, chief and the citizen. Leiden: Leiden University Press.

Trouillot, M.-R. (1995) Silencing the Past: power and the production of history. Boston MA: Beacon Press.

Woodman, G. R. (1996) Customary Land Law in Ghanaian Courts. Accra: Ghana University Press.

Yaro, J. A. (2012) 'Re-inventing traditional land tenure in the era of land commoditization: some consequences in periurban northern Ghana', Geografiska Annaler: Series B, Human Geography 94 (4): 351-68.

\begin{abstract}
This article explores the innovative and hybrid intellectual project of Christopher Azaare Anabila. Since 1976, Azaare has been documenting the histories of the Gurensi and Boosi people of northern Ghana and has crafted genealogical maps of whole villages and clans. He has written manuscripts on taboos, totems, proverbs, missionary activities, cultural institutions and anti-colonial resistance. Because of this work, people have begun to refer to Azaare as Agurumyela, which in Gurene means 'a person who digs into people's past'. Central to this lifelong endeavour is the museum of Gurensi culture that Azaare has been building in Gowrie. I present Azaare's views of this wide-ranging process of collection and re-casting and reflect on his motivation to reclaim history and curating authority from professional academics. I argue that Azaare's project allows us to recognize the ubiquitous existence of a vibrant strand of African intellectual creativity that combines multiple repertoires and draws on overlapping and diverse productions in different modes and media. Next, I turn to Azaare's manuscript on the institution of tindaanaship (earth custodians). I explore his genealogical method as an art of connection that highlights his role as an engaged community intellectual, weaving extensive networks between Gurensi communities, officials and academics.
\end{abstract}

\title{
Résumé
}

Cet article explore le projet intellectuel hybride et innovant de Christopher Azaare Anabila. Depuis 1976, Azaare documente les histoires des Gourounsi et des Bissa du Nord du Ghana et élabore des cartes généalogiques de villages et clans entiers. 
Il a rédigé des manuscrits sur les tabous, les totems, les proverbes, les activités missionnaires, les institutions culturelles et la résistance anti-coloniale. Ces travaux ont valu à Azaare le surnom de Agurumyela qui, dans la langue gourounsi, signifie « une personne qui creuse dans le passé des gens ». Ce travail de toute une vie a pour élément central le musée de la culture gourounsi qu'Azaare a construit à Gowrie. L'auteur présente ce que pense Azaare de ce processus de collecte et de refonte, et s'intéresse à ce qui l'a motivé à se réapproprier l'histoire et l'autorité de conservation, jusqu'alors l'apanage des universitaires professionnels. L'auteur soutient que le projet d'Azaare nous permet de reconnaître l'omniprésence d'un courant dynamique de créativité intellectuelle qui combine de multiples répertoires et s'appuie sur des productions diverses qui se recoupent dans différents modes et médias. Il s'intéresse ensuite au manuscrit d'Azaare consacré à l'institution du tindaanaship (gardiens de la terre). Il décrit la méthode généalogique d'Azaare comme un art de la connexion qui met en lumière son rôle d'intellectuel communautaire engagé, tissant de vastes réseaux entre communautés gourounsi, officiels et universitaires. 